RUNNING HEAD: WHAT IS SO UNAPPEALING ABOUT BLUE FOOD \& DRINK?

\title{
What is so unappealing about blue food and drink?
}

\author{
Charles Spence
}

Crossmodal Research Laboratory, University of Oxford

WORD COUNT: 8,150 WORDS

SUBMITTED TO: INTERNATIONAL JOURNAL OF GASTRONOMY AND FOOD

SCIENCE

DATE: MARCH 2018

CORRESPONDENCE TO: Prof. Charles Spence, Department of Experimental Psychology, University of Oxford, Oxford, OX1 3UD, UK. E-mail: charles.spence@psy.ox.ac.uk. 


\begin{abstract}
During the latter half of the last century, a number of cultural commentators confidently asserted that blue food and drink products would never succeed in the marketplace. How, then, to explain the recent rise of blue drinks in our stores and images of blue foods online? Blue foods are certainly rare in nature, rarer, at least, than foods of other colours. Perhaps as a result, this hue tends to be associated with notions of unnatural and artificial food colouring. That said, 'natural' blue food and drink items are becoming an increasingly common sight in the grocery aisles and online due, in part, to this colour's ability to capture our attention inamongst the other more common food colours. This article highlights those situations/contexts in which blue is/isn't an acceptable food colour, and how attitudes have changed over the decades, in part, due to the emergence of a number of naturally-sourced colouring agents. Ultimately, I consider the question of what, if anything, is stopping us from purchasing/making/consuming more blue food and drink products, and whether or not the current popularity of this colour will last. This review also addresses the question of why it is that blue foods are so rarely seen in chef-prepared meals.
\end{abstract}

KEYWORDS: BLUE; FOOD; DRINK; FOOD COLOUR; UNNATURAL; INSTAGRAM. 


\section{Introduction}

Although rarely seen in natural produce, blue foods and drinks are amongst the most intriguing as far as the psychology of food colouring is concerned. Long written off as a colour that would never work in the grocery store, 'electric blue' has nevertheless achieved quite some prominence in the beverages/drinks aisle in recent decades. Similarly, blue foods/dishes would also currently appear to be experiencing something of a surge in popularity on Instagram (Blake, 2017a). Traditionally, bright blue colour in food and drink was associated with the notion of 'artificial' food colourings (Smithers, 2008), something that has definitely fallen out of favour in recent decades (see Spence, 2015, for a review).

Perhaps unsurprisingly, therefore, the latest blue products to enter the marketplace have mostly tended to stress the natural origins of their colouring agents. In fact, both pea flower and spirulina (and one of the commercial derivatives, Blue Majik; https://www.e3live.com/p7-blue-majik.aspx) are currently popular, adding an eye-catching blue tint to both the blue beverages on our shelves and/or the dishes that many people are uploading onto the internet (Elgart, 2018; Newsome, Culver, \& van Breemen, 2014). However, given its growing popularity, it is worth stressing that this hue works better in certain food and beverage categories than others. Indeed, presumably for evolutionary reasons, blue coloration in meat and fish is generally a much harder sell (Profet, 1992), and, if too vivid, can elicit a powerful aversive response (cf. Wheatley, 1973).

It is interesting to note that in contrast to the beverage brands and food bloggers' obvious fascination with this colour, the modernist chefs have, thus far, largely tended to avoid this hue in the dishes that they serve, not to mention the recipes they provide. ${ }^{1}$ This is presumably

\footnotetext{
${ }^{1}$ I have, for instance, been unable to find any mention of blue food in McGee's (2004) classic volume On Food and Cooking (other than in relation to blue fish and blue cheese), nor in Heston Blumenthal's (2008), The Big Fat Duck Cookbook, nor, for that matter, in Jozef Youssef's (2013) excellent Molecular Cooking.
} 
because there are no flavourful or nutritious ingredients associated with this colour. In other words, in most cases, the only excuse for using this colour in food and drink would seem to be to capture people’s attention.

\section{Historical use of blue food colouring}

Lyall Watson, writing at the start of the 1970s, had the following to say about blue foods: 'We have a deep-seated dislike of blue foods. Take a trip through a supermarket and see how many blue ones you can find. They are rare in nature and equally rare in our artificial hunting grounds. No sweet manufacturer ever successfully marketed a blue confection, and no blue soft drink or ice cream appeared on sale for very long' (Watson, 1971, pp. 66-67). Watson certainly wasn't the only one predicting that blue drinks simply wouldn't sell (see also Cheskin, 1957, for similar claims). ${ }^{2}$ The widespread aversion of consumers to this colour in food, even when the source happens to be entirely natural, was also captured in an article by Tysoe (1985) appearing in the popular psychology press under the header "What's wrong with blue potatoes?"

While Watson (1971) may well have been broadly right in his assertions concerning the rarity of blue foods in the supermarket aisles, he clearly wasn't much of a fan of cocktails. Blue curaçao, after all, has been a regular fixture on the well-stocked cocktail maker's shelf for more than a century now. Bolls Blue liqueur is another bright blue cocktail ingredient (see Sheppard, 2017). ${ }^{3}$ Of course, what goes for cocktails, where nutrition really isn’t a concern, and where playfulness/surprise, not to mention brightly-coloured alcoholic creations (the

\footnotetext{
${ }^{2}$ In the Victorian era, the colour blue was apparently associated with poison (Carter, 2011; see also Burrows, 2009; Downham \& Collins, 2000; Walford, 1980).

3 The liqueur itself is naturally colourless, but is often given an artificial blue, orange, or even green tint. It is unclear when, or why, curaçao was first coloured blue.
} 
more brightly and unusually coloured the better, or so it would seem) are to be applauded need not hold elsewhere (Spence, 2016). So, while the blue lagoon cocktail has fallen out of favour in recent years), ${ }^{4}$ the most incongruent combination of blue colour and orange flavour that is blue curaçao stands as perhaps the longest-lasting and, in many ways, most successful use of blue out there. See Piqueras-Fiszman and Spence (2012) and Velasco, Michel, Youssef, Gamez, Cheok, and Spence (2016), for reviews on the use of colour-flavour incongruency.

Intriguingly, though, pretty much every other example/mention of blue in the world of food and drink that I have come across over the years actually involve its use as a means of discombobulating/confounding the diner/drinker rather than enhancing their experience. So, for example, the legendary Italian Futurist F. T. Marinetti would serve the guests at his Futurist banquets white wine (Castelli Romani) that had been artificially coloured blue (see Marinetti, 1932/2014, p. 184). He didn't stop there, though, as he would also serve orange juice that had been coloured red and milk that had been coloured green.

Meanwhile, a few decades later, the film-maker Alfred Hitchcock served his dinner guests, including Sir Gerald du Maurier, meals that consisted only of foods that had artificially been coloured blue in a private dining room at the Trocadero restaurant in London. Just take the following quote from Hitchcock and Gottlieb (2003, p. 76) to get a sense of how seriously the great film-maker took this task: "And all the food I had made up was blue! Even when you broke your roll. It looked like a brown roll but when you broke it open it was blue. Blue soup, thick blue soup. Blue trout. Blue chicken. Blue ice cream.” A similar blue meal was served to the speakers at the Art and the Senses conference held in Oxford back in August, 2006 (see

\footnotetext{
${ }^{4}$ These days, it certainly feels like cocktail makers are shifting toward the use of more 'natural' ingredients in their drinks.
} 
Spence, Shankar, \& Blumenthal, 2011, p. 208). On that occasion, a blue soup was accompanied by ‘blue’ music - specifically, Miles Davis playing ‘A kind of blue’.

My all-time favourite example of the disconcerting use of blue food colouring comes from a dinner hosted the marketer Wheatley (1973) for a group of 'friends'. The latter were invited to dine on a meal of steak, chips and peas (it was the 1970s after all). The only thing that may have struck any of Wheatley's guests as strange was how dim the lighting at the dining table was. This designed to help hide the food's true colour. When the lighting was returned to normal part of the way through the meal, imagine the guests' horror when they saw that what they had actually been eating was a blue steak, green chips, and red peas. Wheatley gleefully reports how a number of his guests suddenly felt decidedly ill, with some apparently heading straight for the bathroom. ${ }^{5}$ What better evidence could you want to illustrate the power of colour to influence us?

Finally, here, it would be remiss of me not to mention the fabulous Fanny Cradock. For those who are not old enough to remember, she was Britain's first TV celebrity chef (a regular presence on our TV screens in the middle decades of the last century). There are reports of her preparing mashed potatoes in all manner of artificial colours, including blue (see Ellis, 2007). In so doing, Cradock was, I presume, trying to make the artificial colouring of food in unexpected colours into something sophisticated/pleasant (given the tastes of the time). However, that said, there is little evidence to suggest that the British public were convinced to try any of Fanny's blue recipes at home. ${ }^{6}$

In my own work with chefs, I have also seen the negative response that blue foods often evoke. A few years ago, now, for example, I was on stage with the two Michelin-starred

\footnotetext{
${ }^{5}$ Ethics approval not something that one finds in Wheatley's (1973) description of this dinner.

${ }^{6}$ I have also heard rumours that at the end of the Second World War the kids were served mashed potatoes in the colour of the British flag (i.e., blue, red, and white) to celebrate the Allied victory.
} 
Spanish chef Maria Jose San Roman (http://www.monastrell.com/restaurantei.php) at one of Spain’s largest gastronomy festivals (San Román \& Spence, 2009). We were there to talk about the importance of the senses to dining, including, as one might imagine, the importance of vision (or sight), and specifically colour to the diner's appreciation of food and drink. To illustrate the point, Maria Jose had prepared pizzas covered in a dark blue tomato-based topping. However, one only need to take a look at the audience's faces to know how little they enjoyed this particular snack. In a way, then, proving our point.

Meanwhile, Sakai (2011) experimented with colouring sushi blue. As one might have expected, the Japanese participants who took part in this study did not find the miscoloured fish to be very appealing at all. I borrowed this idea for a segment about the importance of colour for a British TV show a couple of years back. Several boxes of store-bought high street sushi were dipped (the fish that is) in blue food dye. Even though the sushi itself was perfectly fresh, and didn't taste any different from normal (given that the food dye had been chosen to be effectively odourless and tasteless), it was virtually impossible to get any of the guests on the show to put the sushi into their mouths! That this wasn't simply a matter of the guests not being hungry was amply illustrated when after the cameras stopped rolling we brought out a box of unadulterated sushi, which all soon disappeared.

In terms of peer-reviewed empirical research on the consequences for consumption of colouring food blue, we need to turn to Suzuki, Kimura, Kido, Inoue, Moritani, and Nagai (2017). These researchers assessed the impact on consumption of colouring a commerciallyproduced white potage soup blue or yellow by the addition of food dyes (see Figure 1). During the test, 12 young females' had to report on their impression of the soup prior to tasting, rating their willingness to eat, palatability, comfort, warmth, and anxiety using visual analog scales. Perhaps unsurprisingly, the participants reported being less willing to eat the blue soup than the soup of either of the other colours. Furthermore, the blue soup also gave 
rise to a significant increase in feelings of anxiety compared to the white and yellow soups. Expected palatability, comfort, and warmth ratings were also all lower for the blue soup on visually-inspecting it prior to tasting. After consumption, the blue soup was also rated as less satiating.

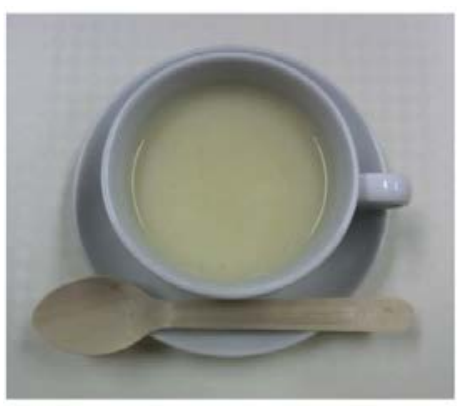

( A )

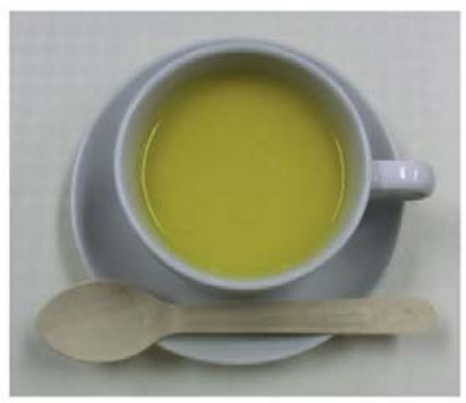

( B )

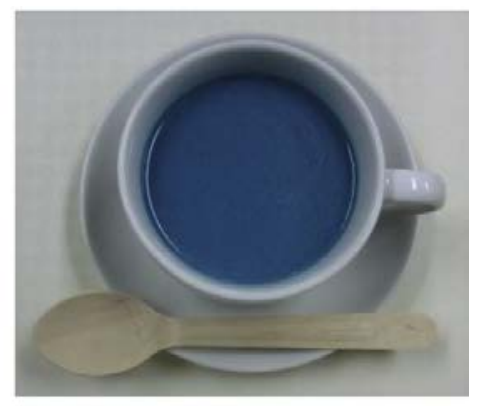

( C )

Figure 1. The three different colored soups: (A) white, (B) yellow, and (C) blue presented to participants in Suzuki et al.’s (2017) study. [Figure reproduced with permission]

\section{Background blue and its impact on food behaviour}

It is worth noting that the negative response of consumers to the colour blue extends beyond the colour of the food itself. A blue background while dining has also been reported to be offputting. This, apparently, was the logic behind the blue tray meal deal of depression era North America. The suggestion was that those offering all-you-can-eat meals realized that customers consumed less food if they were given a blue tray rather than a tray of another colour. Crumpacker (2006, p. 143) claims that “...the term blue plate special became popular during the Great Depression because restaurant owners found that diners were satisfied with 
smaller portions of food if it was served on blue plates."7 Intriguingly, recent research has also shown that blue crockery influences the perceived taste of everything from popcorn (Harrar, Piqueras-Fiszman, \& Spence, 2011) through to milk coffee drinks (Van Doorn, Wuillemin, \& Spence, 2014; see also Lyman, 1989, p. 112).

Cho, Han, Taylor, Huck, Mishler, Mattal, Barker, and Seo (2015) reported that Swedish men (but not Swedish women) tended to eat less for breakfast under blue lighting but to feel no less satiated. Several other studies have also demonstrated that blue lighting impairs people’s perception (or the eye appeal) of various fruits and vegetables (see Hasenbeck, Cho, Meullenet, Tokar, Yang, Huddleston, et al., 2014; Suk, Park, \& Kim, 2012; Yang, Cho, \& Seo, 2016).

\section{Interim summary}

All of the examples mentioned so far, albeit mostly anecdotal, would nevertheless lead one to think that Watson (1971) was right: That is, consumers really do not appear to have much of a stomach for blue food (nor perhaps even for blue surroundings when eating/drinking). Indeed, commercial attempts to introduce blue have often failed in the marketplace, such as in the case of blue tomato ketchup (Farrell 2000; Spector, 2011) and blue margarine (Garber et al., 2008). Of all the hues, blue would seem to induce the strongest reactions (no matter whether one is thinking positive or negative). The one exception, as we have seen already, comes from the world of cocktails, which may be a special case (i.e., because of its playfulness and the lack of connection to nutrition; Spence, 2016). This aversion to blue in, or around, food, is so striking especially because it stands in contrast to the general literature on

\footnotetext{
${ }^{7}$ That said, and in contrast to the idea behind the blue tray meal deal, a number of start-ups selling high contrast blue (and red) plates to help older patients who may be having some difficulties seeing their food to enhance the contrast, and so get them to eat more (e.g., Adams, 2013; Hultén, Broweus, \& van Dijk, 2009; Spence, 2017a).
} 
colour preferences, where blue often comes out as the most preferred colour (e.g., Dittmar, 2001), and is also a highly preferred colour in art (Dutton, 2009; Pastoureau, 2000). Intriguingly, some (food) artists have also chosen to colour foods blue in their order to deliberately make them look most unappealing (see Figure 2).

A)

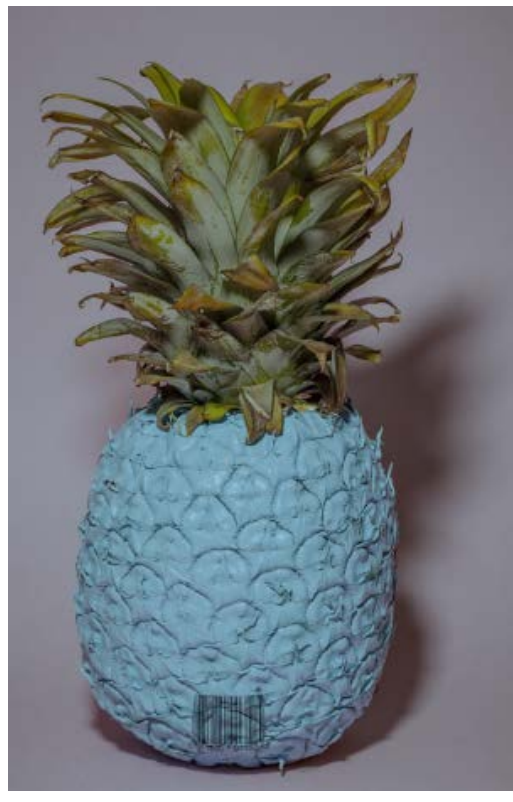

B)

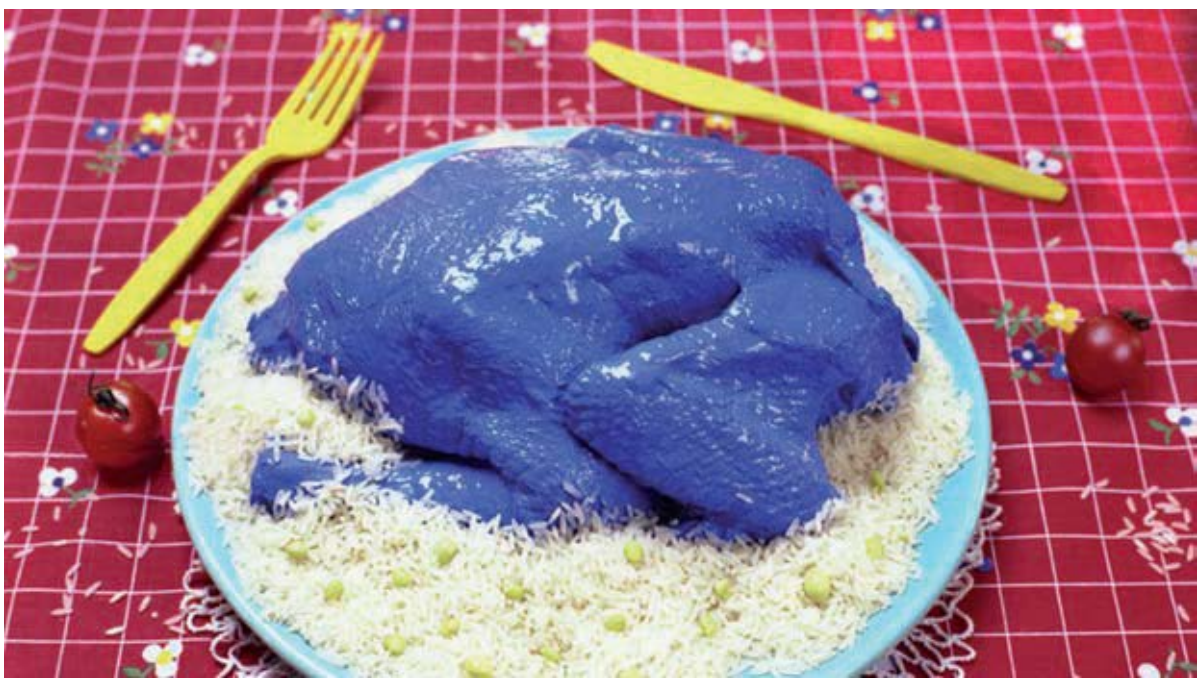

Figure 2. A) An unappealing blue pineapple. This from a project on surreal still lifes of genetically modified fruit by German photographer Enrico Becker and Matt Harris (Ivanova, 2015). B) Blue chicken anyone? Incongruently colouring can be most unappealing in certain contexts (courtesy of Lawrie Brown, http://lawriebrown.com/foodpage.html, coloured food series; Poon 2014). 


\section{What is it about blue in food that people do/do not like?}

So what is it about blue in food that people really dislike? Is it the rarity of the colour in natural foods that makes people wary (Cardello, 1996; Newsome et al., 2014)? Or is rather it that the majority of examples of blue in food and drink that have hit the high streets in previous decades have been associated with artificial blue food colouring, and it is that that people really do not like, or are wary about (e.g., Kobylewski \& Jacobson, 2010)? Here I am thinking of blue Smarties (Smithers, 2008), brightly-coloured Froot Loops breakfast cereal, and Kool-Aid. Alternatively, it might be that in our evolutionary pat those foods that turned blue may have gone mouldy, and so should probably be avoided to avoid poisoning (Piqueras-Fiszman, Kraus, \& Spence, 2014). And beyond these possibilities, another reason as to why people may not like blue foods may be related to the consequences of negative peer modelling (see Greenhalgh, Dowey, Horne, Lowe, Griffiths, \& Whitaker, 2009). Clearly, understanding the source of consumers' aversion to blue in food and drink is going to be important if we are to change their behaviour.

\section{Artificial blue food colouring}

The problem with blue, at least in the mind of many consumers out there, is that it is an 'unnatural' colour as far as food and drink are concerned. However, the brighter stronger colours (associated as they are in the consumers' mind with notions of artificiality and hence unhealthy) do seem to be on the decline. Indeed, the last few years have seen a shift to natural/paler colours. So, for example, here in the UK, blue Smarties were dropped in 2005 by Nestle over concerns about the use of artificial food colourings, only to be reintroduced 
once a natural blue colouring agent had been found. Meanwhile, the children's breakfast cereal Froot Loops also got much paler a few years ago, once the artificial colours were removed (Licata, 2015). The decline in blue cocktails is, in part, I think also linked to a shift toward a more natural product offering. It would seem that the consumer doesn't always have an appetite for blue foods.

\section{Naturally blue foods}

The focus on artificially-coloured blue food and beverage products misses, though, the fact that there are a number of naturally blue foods out there. These include blue potatoes (such as the Blue Congo variety; Carter, 2011; Paaki, Sandell, \& Hopia, 2016). Indeed, recipes using blue potatoes to add an unusual dash of colour are also more popular than ever on the internet (e.g., see https://www.vegan.com/recipes/blue-mashed-potatoes/; http://www.foodnetwork.com/recipes/blue-potatoes-mashed-with-roasted-garlic-recipe1911752; this suggesting a change in attitude from when Tysoe (1985), wrote an article asking why blue potatoes were so unpopular). And then there are, of course, blueberries and blue corn (with the colouring in the latter attributable to the presence of anthocyanins; Ossola, 2016). Blue lobsters also occur in nature (albeit being very, very rare). In this case, though, it is the hard carapace, not the flesh itself that is blue, rather than its usual white (Parkinson, 2016). Similarly, there is a blue fish that has a blueish sheen prior to removing the skin (see McGee, 1984/2004). Notice how the blue colour in such cases does not seem to evoke anything line the same displeasure/aversion in people.

Blue is also the colour of the veining in blue cheeses such as Roquefort, Gorgonzola, Stilton, and Oxford Blue. This blue streaking, attributable to the presence molds such as Penicillium roqeforti and $P$. glaucum is, in fact, a desirable attribute of this food and is responsible for 
what Harold McGee terms 'the characteristic blue aroma' (McGee, 1984/2004, p. 59). And then there are those who appreciate a hint of blue in the red of their ever-so-lightly cooked steak too. Though, that said, the liking for such 'natural' blue foods would seem to occur somewhat later in life (Davies, 2015), whereas many of the brightly, artificially coloured foods were clearly targeted at the youth market. Research by Paaki et al. (2016) with Finnish consumers suggests that it is the variety-seeking/neophilic consumers who are more likely to like unusually-coloured foods such as blue potatoes (Januszewska \& Viaene, 2012; Pliner \& Hobden, 1992).

\section{Blue beverages}

Blue drinks started to appear in the beverage/drinks aisle subsequent to Watson's (1971) negative pronouncement. Their growing popularity spear-headed by the likes of Slush Puppy, Gatorade, and Kool-Aid. ${ }^{8}$. But why introduce this most unnatural colour into the soft drinks category in the first place? The suggestion is that marketers are fond of this colour because of its ability to stand out on the shelf, when placed in-amongst all those natural fruit colours (Garber, Hyatt, \& Boya, 2008). The concept of a 'Blue Raspberry' fruit-flavoured drink (also popular as a variety of Kool-Aid) may have worked so well initially precisely because consumers had no specific expectations associated with that particular colour, at least not when the drink was situated in the soft drinks aisle. ${ }^{9}$

\footnotetext{
8 Gatorade also offer a beverage line called "Blue Bolt".

${ }^{9}$ While blue in a sports drink would not initially have set any expectations, the colour was at least congruent with the notion of an ice-cold refreshing beverage (Garber et al., 2008). This can be contrasted with Clear Tab cola that failed because the consumer already had a pre-existing association with lemonade/soda water (Spence \& Piqueras-Fiszman, 2012). The importance of this brought home by the case of clear Tab cola. A drink that looked like lemonade, Sprite, or carbonated water, but which tasted of cola. It failed miserably in the marketplace and was soon withdrawn.
} 
So, have the marketers succeeded in teaching the consumer a new association with blue in the soft drinks aisle? What flavour, in other words, does the blue colour elicit in consumers nowadays? In 2010, we attempted to answer this question by conducting a cross-cultural study in which six differently-coloured drinks were shown to young consumers from the UK and Taiwan (Shankar, Levitan, \& Spence, 2010). The latter had to say what flavour they expected the drink would have. Relevant here, one of the drinks was a clear blue drink (see Figure 3A). In this case, the young Brits who took part in this study thought that the drink would have a raspberry flavour (mint and blueberry were the next most common choices). The young Taiwanese participants who were quizzed thought of mint (i.e., mouthwash) instead (the second most popular suggestion was cocktail). Such results clearly demonstrate that the marketers have had some success in convincing the consumer (at least the young British consumer) that a clear blue drink (at least when presented as a soft drink) does indeed signal raspberry flavour.

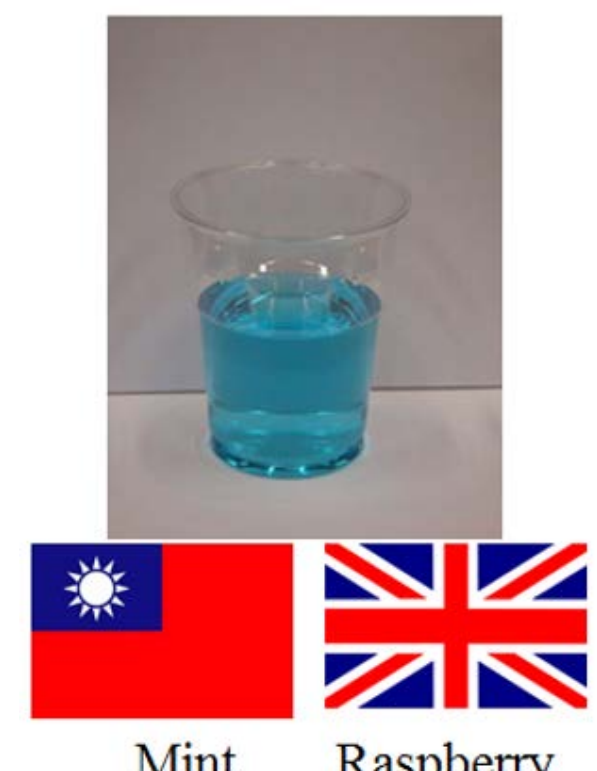

A)
Raspberry
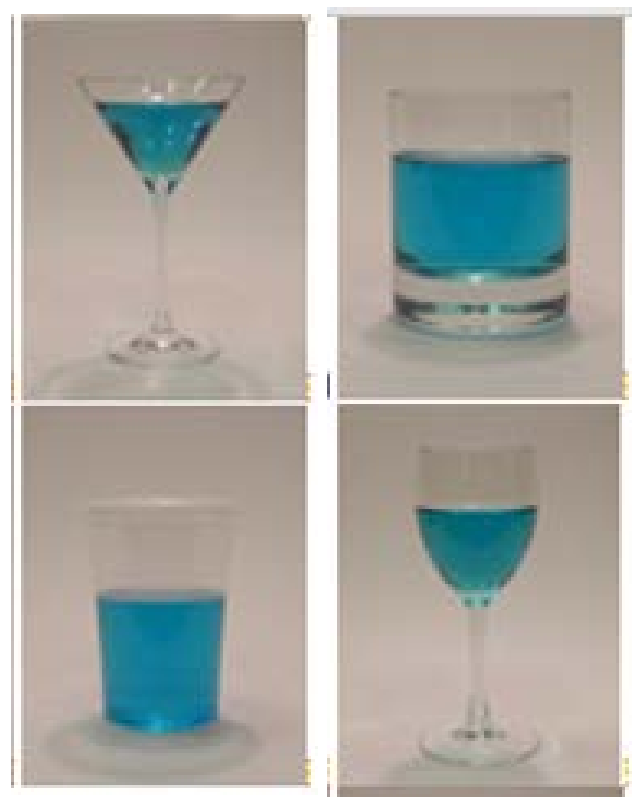

Figure 3. A) Blue drink shown to the participants in Shankar et al.'s (2010) study in a plastic cup. B) The four drinking receptacles in which coloured 
drinks were shown to the participants in Wan et al.’s (2014a) internet-based study.

More recently, we conducted a largescale study on more than 5000 individuals as part of the Cravings Exhibition held at the Science Museum in London. Those who took part were simultaneously shown pictures of blue, green, orange, purple, red, and yellow drinks in plastic cups and had to pick the drink colour that looked sweetest (Velasco et al., 2016). Interestingly, the blue drink turned out to be the second most popular choice after red (garnering $28 \%$ and $41 \%$ of the votes, respectively; see also Alley \& Alley, 1998; Koch \& Koch, 2003). People appear to bring to mind exemplars when trying to interpret or assess the taste meaning of colour (Saluja \& Stevenson, in press). ${ }^{10}$ Figure 4 highlights one artists representation of all things blue in the world of food and drink.

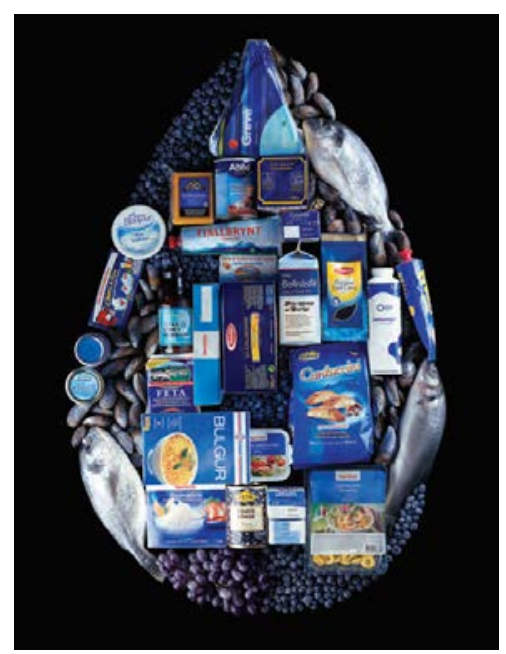

Figure 4. Artistic arrangement of blueish foods and food packaging. [From Stewart (2011).]

\footnotetext{
${ }^{10}$ People associate the colour blue (and white) with salt taste (e.g., Spence, Wan, Woods, Velasco, Deng, Youssef, \& Deroy, 2015; Wan, Woods, van den Bosch, McKenzie, Velasco, \& Spence, 2014b; Woods, Marmolejo-Ramos, Velasco, \& Spence, 2016; Woods \& Spence, 2016), based, presumably, on the use of that colour-taste correspondence in the world of product packaging.
} 
That said, the meaning of a drink's colour in the mind of the consumer can sometimes be influenced by the specific context in which it is seen. One important, if oft-neglected, component of the context is the specific receptacle in which a drink is seen. Relevant here, Wan, Velasco, Michel, Mu, Woods, and Spence (2014a) conducted a study in which photographs of blue, red, green, yellow, orange, brown, and clear liquids displayed in a water glass, a wine glass, a cocktail glass, and a plastic cup (making for a total of 28 different drinks) were shown to consumers from the USA and mainland China (see Figure 3B for a subset of the visual stimuli). Interestingly, however, while cross-cultural differences were once again observed in the expected flavour associated with the blue drinks, these expectations were not influenced by the receptacle in which the drinks were presented (though responses to a number of the other beverage colours were affected by the receptacle in which the coloured liquids were shown). For all of the consumers, blueberry was the dominant flavour response on seeing the blue drink amongst. However, raspberry followed by mint were the two next most popular choices for the North American participants whereas it was mint and 'other' that came next for those from mainland China.

\section{On the rise of foods that use natural blue food colouring}

The colour blue, then, has become more popular in the marketplace. This is presumably because marketers are increasingly coming to realize the benefits of colouring their food and beverage products in ways that can easily capture the attention of the consumer by standing out on the shelf (Carter, 2011). However, in contrast to the just-mentioned soft drinks, the latest blue drink offerings are all very careful to stress the 'natural' origins of their colour. First in the alcoholic drinks category came the blue gins: e.g., Edgerton Blue Spice Gin (e.g., 
Kiely, 2015) and Blue Magellan gin. The latter coloured with iris flowers (http://www.magellangin.com/faqhowdoesmagellan.html). Such unusually-coloured spirits will undoubtedly capture attention on the shelf (at least while there aren't too many blue spirits out there). That said, one still has to be careful.

What, exactly, are the expectations set by the pale colour of these spirits? Raspberry, like the intensely blue-coloured soft drinks, or something different? Interestingly, we were commissioned to conduct research on behalf on one gin brand a few years ago in order to help them understand why it was that consumers were not entirely happy with their coloured gins which came in a pale pink and blue colour. Closer analysis revealed that the pink colour set expectations of red fruit flavours that did not necessarily follow-through on the nose or palate. That said, there was little evidence to suggest that consumers expected to smell raspberry when sniffing the blue gin.

Meanwhile, in an unacknowledged nod to the Italian Futurists (Marinetti, 1932/2014), GiK blue wine launched in Spain in 2016 (apparently coloured with organic indigo and anthocyanin pigments; see Hohendahl, 2016). The Italians themselves have been selling Blumond, a blue sparkling wine consisting of curaçao, peach, and prosecco (Marchetti, 2017), 'naturally' coloured blue with pea flower. Let's see how they last in the marketplace. The suggestion from the marketing team at GiK is that their blue wine is targeted at the Millennials (Hohendahl, 2016). But, one has to ask, are blue wine drinks really what the latter want. The problem here, at least as far as I see it, is that the subtle gradations of colour carry such meaning in the world of wine, even for those who don't consider themselves wine experts (Spence, 2010a, b). Hence, my fear is that obscuring those 'informative' colour cues may cause more trouble than when colouring a naturally clear drink (such as London dry gin, 
though note that one can no longer give it that moniker once it has been coloured). ${ }^{11}$ Intriguingly, giving a drink a blue hue may result in drinkers suffering less from the consequences of the alcohol that they have consumed. That, at least, would seem to be the conclusion from a study conducted by Remington, Roberts, and Glautier (1997). These researchers demonstrated that the British students $(\mathrm{N}=20)$ tested in this study were less influenced by the alcohol that they had just consumed if presented as an unfamiliar blue peppermint drink rather than when the same amount of alcohol was consumed in a much more familiar format, namely beer.

Over the last couple of years, blue spirulina (commercialized as Blue Majik) has proved something of a hit amongst those posting Instagram pictures of food/dishes (Elgart, 2018). By contrast, as mentioned earlier, there has been surprisingly little uptake from chefs themselves. Why the disconnect? Perhaps the idea of adding an ingredient solely for the colour that it may add to a dish, is anathema? Indeed, part of the growth of interest in blue foods may simply be being driven by the rise of gastroporn (Spence, Okajima, Cheok, Petit, \& Michel, 2016). Photographing a dish that is, in part, blue is certainly likely to create a more arresting image. And, as some have noted, there is little interest in actually consuming some of these dishes....that they look good is the thing. Indeed, this was part of the concern that led to the Uninstagrammable Dish (see Spence, 2017b). At present, it feels like it is all about capturing the consumer's attention. And one way of doing this is through the use of unusual, but crucially, natural colours (see Figure 5). ${ }^{12}$

\footnotetext{
${ }^{11}$ Blumond, while already sold in China and North America certainly managed to offend the sensibilities of the Italian wine world. Just take the following from Marchetti (2017): "Then there is the colour which offends the sensibilities of Italy's most famous winemakers. Wladimiro Gobbo, a member of Italy's Sommelier Association said that Blumond is 'simply an insult to our wine tradition'. He said: 'It's embarrassing. These are not wines but coloured liquids, dumb-downed hybrids with a watered-down percentage of alcohol'. Fabio Lantieri de Paratico, co-founder of the consortium that protects Franciacorta, Italy's niche bubbly, added: 'These do not belong to our world. They're just whims and trends that come and go'."

${ }^{12}$ Just take the following quote from Susi Richards, head of product development at Sainsbury's: "Colour is really, really important in food products because customers tell us if something looks colourful, they think it's
} 


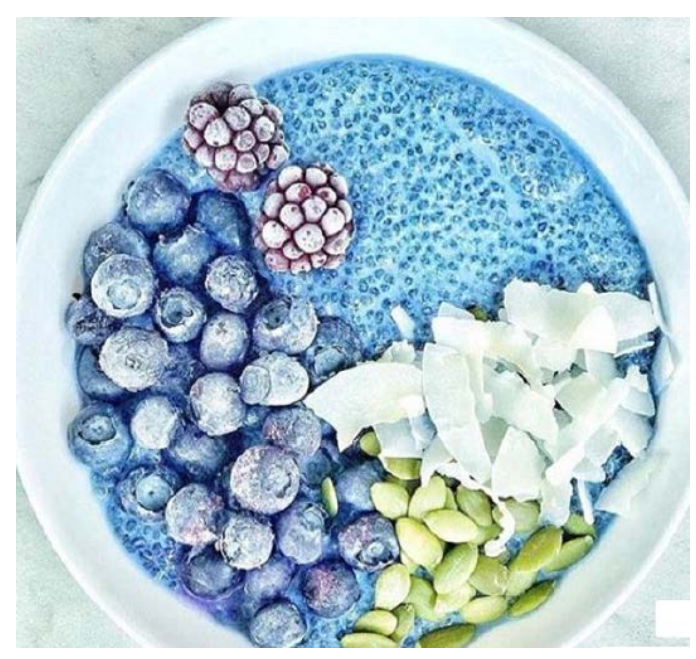

Figure 5. Blue Majik (an extract of spirulina, a blue-green algae) saw a huge rise in popularity in 2017: Recently, there has been a craze to use this the bright blue hue of this algae powder (the blue hue coming from Cphycocyanin) in order to capture attention online (e.g., on social media). This colouring agent is sold as a superfood supplement with health benefits (attributable to anti-inflammatory properties), though there is some question over the latter claim. The powder is apparently also a rich source amino acids, antiodixants, and nutrients, enzymes, vitamins, and nutrients. ${ }^{13}$ However,

\section{Blue medicines}

Away from the world of food and drink, blue is not necessarily an aversive colour to ingest or take into the oral cavity. Certainly, the makers of Viagra would not seem to think so. After

\footnotetext{
healthy and nutritious and so good for them - cues we are now working to strengthen across a wide range of our products... It's all about using naturally occurring colours to stand out, nothing artificial." The article in which this quote appears continues: "The supermarket recently began selling the Purple Majesty purple potato alongside red oranges and yellow raspberries, and it will introduce a candy-striped beetroot later this year." (Carter, 2011).

${ }^{13}$ However, according to those who have tried it, it has a strong and revolting taste of fish. (see Music, 2017, quoted in Elgart, 2018). Perfect, then, for social media if not for delivering a great tasting food.
} 
all, this best-selling drug was intentionally coloured blue, presumably because of this colour's association with relaxation (Wan et al., 2015). ${ }^{14}$ In fact, many medicinal products are coloured blue, including minty blue mouthwash (see also Parise \& Spence, 2012). In this case, the blue liquid is certainly something that people are happy to put in their mouth, but is should definitely not be swallowed.

\section{Conclusions}

In the past, artificial blue food colouring was often used to discombobulate people (e.g., Hitchcock \& Gottlieb, 2003; Ivanova, 2015; Marinetti, 1932/2014; Poon, 2014; San Roman \& Spence, 2011; Sheppard, 2017; Suzuki, 2011; Wheatley, 1973). Indeed blue was written off by some authors as a colour that consumers would never like in food (e.g., see Watson, 1971). That said, there are some categories, drinks in particular (such as cocktails, and blue soft drinks) where blue has been successfully used to market a product. Similarly, blue is seemingly also a desirable colour in medicinal products, such as mouthwash and Viagra (e.g., Parise \& Spence, 2012; Wan et al., 2015). Bright blue food colourings have also been popular amongst those foods targeted at children, and this has led to worries about the use of artificial and 'unnatural' chemicals in our foods. The problem, as we have seen, is that blue foods and blue drinks can all-too-easily prime notions of artificial/synthetic in the mind of the consumer. Crucially, it is the belief, as much as the reality of the situation, that is likely key in determining the success of such innovations in the marketplace.

\footnotetext{
${ }^{14}$ One amusing example of the cross-cultural differences in the meaning of colour comes from research suggesting that while blue is a relaxing colour for most people (and hence is a good colour for a calming pharmaceutical product, say), the one group who have been demonstrated to show the opposite response is Italian men (Lucchelli, Cattaneo, \& Zattoni, 1978). The latter, apparently, can't help seeing a dark blue colour without also thinking about the distinctive strip of their national football team, the Azurros! In line with this suggestion, recent findings have shown that the colour of one's sports team can indeed change a person's response to colour (Schloss, Poggesi, \& Palmer, 2011). Clearly, then, we have a different response to blue in a medicinal context. Viagra, after all, also comes in a 'relaxing' blue colour (see also Wan, Woods, Velasco, Salgado-Montejo, \& Spence, 2015, on people's associations with blue pharmaceuticals).
} 
In this context, it is interesting to note how many of those who have launched blue drinks or colouring agents into the marketplace in recent years, and those posting the culinary creations onto the internet, tend to use a natural source of dye (such as from blue spirulina). ${ }^{15}$ Blue clearly sells when the natural source of the food colouring is stressed. However, whatever the source of the colour, its use only really makes sense as a means of capturing people's attention and standing out from the crowd. In the alcoholic and non-alcoholic drinks categories (including cocktails) blue looks to retain its status as an attention-capturing colour. That said, I do not believe that the recently-introduced blue wine drinks have much of a future, given the importance of subtle colour cues to our appreciation and understanding of products in this category (Spence, 2010a, b).

Will blue food and drink offerings continue to rise in popularity? It is certainly a most instagrammable colour (Elgart, 2018), no doubts about that. And given the seemingly unstoppable rise in gastroporn (Spence et al., 2016), blue food colouring would definitely seem to have a bright future. One innovative solution to the potential conflict between blue as a visually attention-capturing food colour on the one hand, and one that is not necessarily appealing on the other comes from Yumchaa's recently-launched colour-changing Blue Voodoo Magic Tea. When lemon is added, this turquoise blue tea transforms into a more appealing deep purple colour (see Blake, 2017b). Once again, the natural sourcing of the colouring (dried pea flowers) is emphasized. ${ }^{16}$

So, ultimately, while blue foods were once written-off, this hue has seen something of a resurgence, though not in the world of gastronomy, where those colours that are more associated with nature would seem to be preferred (e.g., Lightner \& Rand, 2014). Ultimately,

\footnotetext{
${ }^{15}$ Rietz (1961) also lists indigo, campeachy, violet, and cudbear as botanical sources of blue food colouring.

16 The colouring agent used in this tea is $\mathrm{pH}$ sensitive, hence explaining the change in colour in response to the addition of the acidic lemon.
} 
blue's introduction into food and drink would seem to be more about capturing the attention of the consumer (be it on the shelf, or on one’s Instagram feed), and very little to do with any attempt to actually enhance the taste/flavour or nutritional value of an offering. It is for this reason, then, that so few chefs, even those of a modernist persuasion, have been tempted to dish up much in the way of blue food thus far. And while food futurology is undoubtedly a risky business (see Spence \& Piqueras-Fiszman, 2014, on this theme), I, for one, can see little reason to believe that this state of affairs will change any time soon.

\section{REFERENCES}

Adams, S. (2013). How to rescue NHS food? Put it on a blue plate: Simple switch has helped elderly and weak patients eat nearly a third more. DailyMail Online. http://www.dailymail.co.uk/news/article-2520058/How-rescue-NHS-food-Put-blue-plateSimple-switch-helped-elderly-weak-patients-eat-nearly-more.html.

Alley, R. L., \& Alley, T. R. (1998). The influence of physical state and color on perceived sweetness. Journal of Psychology: Interdisciplinary and Applied, 132, 561-568.

Blake, I. (2017a). The WEIRDEST food trends of the last year that WON'T be on the table in 2018 (including brightly coloured 'unicorn' meals and cloud eggs). Daily Mail Online, December 30 ${ }^{\text {th }}$. http://www.dailymail.co.uk/femail/food/article-5220549/The-WEIRDESTfood-trends-2017-WONT-last.html.

Blake, I. (2017b). Too pretty to drink? Sell-out colour-changing tea turns from blue to purple before your eyes (and it's flying off shelves faster than classic Earl Grey). Daily Mail Online, September 25 $^{\text {th }}$. http://www.dailymail.co.uk/femail/food/article-4910522/The-viral-colourchanging-tea-s-selling-fast.html.

Blumenthal, H. (2008). The big Fat Duck cookbook. London, UK: Bloomsbury.

Burrows, J. D. (2009). Palette of our palates: A brief history of food coloring and its regulation. Comprehensive Reviews of Food Science \& Food Safety, 8, 394-408.

Cheskin, L. (1957). How to predict what people will buy. New York, NY: Liveright.

Cardello, A. V. (1996). The role of the human senses in food acceptance. In H. L. Meiselman \& H. J. H. MacFie (Eds.), Food choice, acceptance and consumption (pp. 1-82). New York: Blackie Academic and Professional.

Carter, M. (2011). All things bright and edible: Fancy some black garlic, blue potatoes or red cake? The Independent, April 21 ${ }^{\text {st }}$.

Cho, S., Han, A., Taylor, M. H., Huck, A. C., Mishler, A. M., Mattal, K. L., Barker, C. A., \& Seo, H.-S. (2015). Blue lighting decreases the amount of food consumed in men, but not in women. Appetite, 85, 111-117. 
Crumpacker, B. (2006). The sex life of food: When body and soul meet to eat. New York, NY: Thomas Dunne Books.

Davies, M. (2015). How AGE affects our taste in food: We only start liking olives, anchovies and blue cheese in our twenties, survey reveals. Daily Mail Online, February $12^{\text {th }}$. http://www.dailymail.co.uk/health/article-2950608/How-AGE-affects-taste-food-start-likingolives-anchovies-blue-cheese-twenties-survey-reveals.html.

Dittmar, M. (2001). Changing colour preferences with ageing: A comparative study on younger and older native Germans aged 19-90 years. Gerontology, 47, 219-226.

Downham, A., \& Collins, P. (2000). Colouring our foods in the last and next millennium. International Journal of Food Science and Technology, 35, 5-22.

Dutton, D. (2009). The art instinct. Oxford, UK: Oxford University Press.

Elgart, B. (2018). BLUE-tiful! Healthy living gurus flood social media with beautiful snaps of dishes made using trendy superfood Blue Majik - but is the picture perfect powder REALLY that healthy? Daily Mail Online, January $\mathbf{1 9}^{\text {th }}$. http://www.dailymail.co.uk/femail/article-5252013/Blue-Majik-latest-Instagramobsession.html

Ellis, C. (2007). Fabulous Fanny Cradock. Stroud, UK: Sutton Publishing.

Farrell, G. (2000). What's green. Easy to squirt? Ketchup! USA Today, July 10 ${ }^{\text {th }}, 2 \mathrm{~b}$.

Garber, L. L. Jr., Hyatt, E. M., \& Boya, Ü. Ö. (2008). The mediating effects of the appearance of nondurable consumer goods and their packaging on consumer behavior. In $\mathrm{H}$. N. J. Schifferstein \& P. Hekkert (Eds.), Product experience (pp. 581-602). London, UK: Elsevier.

Greenhalgh, J., Dowey, A. J., Horne, P. J., Lowe, C. F., Griffiths, J. H., \& Whitaker, C. J. (2009). Positive- and negative peer modelling effects on young children's consumption of novel blue foods. Appetite, 52, 646-653.

Harrar, V., Piqueras-Fiszman, B., \& Spence, C. (2011). There's no taste in a white bowl. Perception, 40, 880-892.

Hasenbeck, A., Cho, S., Meullenet, J. F., Tokar, T., Yang, F., Huddleston, E. A., et al. (2014). Color and illuminance level of lighting can modulate willingness to eat bell peppers. Journal of the Science of Food and Agriculture, 94, 2049-2056.

Hitchcock, A., \& Gottlieb, S. (Ed.). (2003). Alfred Hitchcock: Interviews. Jackson: University of Mississippi Press.

Hohenadel, K. (2016). Is blue wine the new rosé? Slate Magazine, June $\mathbf{2 3}^{\text {rd }}$. http://www.slate.com/blogs/the_eye/2016/06/23/gik_wants_to_sell_blue_wine_as the_drink _of_hipster_millennials.html.

Hultén, B., Broweus, N., \& van Dijk, M. (2009). Sensory marketing. Basingstoke, UK: Palgrave Macmillan.

Ivanova, A. (2015). Surreal still lifes of genetically modified fruit. Still Life Project, September $\mathbf{2 9}^{\text {th }}$. Downloaded from http://thecreatorsproject.vice.com/nl/blog/genetischgemanipuleerdfruitzoueigenlijkheleandere kleurenmoetenhebben on 15/12/2015.

Januszewska, R., \& Viaene, J. (2012). Sensory evaluation of traditional products by varietyseekers and food neophobics. Journal of Culinary Science \& Technology, 10, 192-210. 
Kiely, M. (2015). Edgerton launches 'world's first' blue spice gin. Drinks Business, July $3^{\text {rd. }}$ http://www.thespiritsbusiness.com/2015/07/edgerton-launches-worlds-first-blue-gin/.

Kobylewski, S., \& Jacobson, M. F. (2010). Food dyes: A rainbow of risks. Center for Science in the Public Interest, June 29 ${ }^{\text {th }}$. http://cspinet org/new/201006291.html (accessed 21 March 2011).

Koch, C., \& Koch, E. C. (2003). Preconceptions of taste based on color. Journal of Psychology: Interdisciplinary and Applied, 137, 233-242.

Licata, E. (2015). Kellogg's announces plans to get rid of artificial colors and flavors, so prepare yourself for some sad, pale Froot Loops. Mommyish, August $\mathbf{6}^{\text {th }}$. http://www.mommyish.com/kelloggs-artificial-color-flavor-froot-loops/.

Lightner, M., \& Rand, S. (2014). The enhancement of natural colors to provoke seasonality International Journal of Gastronomy and Food Science, 2, 55-59.

Lucchelli, P. E., Cattaneo, A. D., \& Zattoni, J. (1978). Effect of capsule colour and order of administration of hypnotic treatments. European Journal of Clinical Pharmacology, 13, 153155.

Lyman, B. (1989). A psychology of food, more than a matter of taste. New York, NY: Avi, van Nostrand Reinhold.

Marchetti, S. (2017). Red or white? Now Italy may get BLUE wine - but purists say it's an insult to national tradition. Daily Mail Online, April 29 ${ }^{\text {th }}$.

Marinetti, F. T. (1932/2014). The futurist cookbook (Trans. S. Brill, 1989). London, UK: Penguin Books.

McGee, H. (1984/2004). On food and cooking: The science and lore of the kitchen (rev. ed.). New York, NY: Scribner.

Music, C. L. (2017). I spent an entire week trying to make spirulina taste good. Bon Appetit, March 31 ${ }^{\text {st }}$. https://www.bonappetit.com/story/how-to-use-blue-majik.

Newsome, A. G., Culver, C. A., \& van Breemen, R. B. (2014). Nature's palette: The search for natural blue colorants. Journal of Agricultural \& Food Chemistry, 62, 6498-6511.

Ossola, A. (2016). Why are so few foods blue? Kitchn, June $\mathbf{1 3}^{\text {th }}$. https://www.thekitchn.com/why-are-so-few-foods-blue-231706.

Paakki, M., Sandell, M., \& Hopia, A. (2016). Consumer's reactions to natural, atypically colored foods: An investigation using blue potatoes. Journal of Sensory Studies, 31, 78-89.

Parise, C. V., \& Spence, C. (2012). Assessing the associations between brand packaging and brand attributes using an indirect performance measure. Food Quality and Preference, 24, 17-23.

Parkinson, J. (2016). How rare are bright blue lobsters? BBC News Online, May $\mathbf{2 5}^{\text {th }}$. http://www.bbc.co.uk/news/magazine-36369687.

Pastoureau, M. (2000). Blue: The history of a color. Princeton: Princeton University Press.

Piqueras-Fiszman, B., Kraus, A., \& Spence, C. (2014). "Yummy” versus “yucky”! Explicit and implicit approach-avoidance motivations toward appealing and disgusting foods in normal eaters. Appetite, 78, 193-202.

Piqueras-Fiszman, B., \& Spence, C. (2012). Sensory incongruity in the food and beverage sector: Art, science, and commercialization. Petits Propos Culinaires, 95, 74-118. 
Pliner, P., \& Hobden, K. (1992). Development of a scale to measure the trait of food neophobia in humans. Appetite, 19, 105-120.

Poon, L. (2014). Tasting with our eyes: Why bright blue chicken looks so strange. http://www.npr.org/sections/thesalt/2014/04/16/303215873/tasting-with-our-eyes-whybright-blue-chicken-looks-so-strange.

Profet, M. (1992). Pregnancy sickness as adaptation: A deterrent to maternal ingestion of teratogens. In J. H. Barkow, L. Cosmides, \& J. Tooby, (Eds.), The adapted mind: Evolutionary psychology and the generation of culture (pp. 327-365). Oxford, UK: Oxford University Press.

Remington, B., Roberts, P., \& Glautier, S. (1997). The effect of drink familiarity on tolerance to alcohol. Addictive Behaviors, 22, 45-53.

Rietz, C. A. (1961). A guide to the selection, combination and cooking of foods. Westport, Conn.: Avi.

Sakai, N. (2011). Tasting with eyes. i-Perception, 2(8), http://iperception.perceptionweb.com/journal/I/article/ic945.

Saluja, S., \& Stevenson, R. J. (in press). Cross-modal associations between real tastes and colors. Chemical Senses.

San Román, M.-J., \& Spence, C., (2009). Experiencias sensoriales practices alucinantes en la gastronomía. Invited presentation given at the XI Congreso lo Major de la Gastronomia. $8^{\text {th }}$ November. Alicante, Spain.

Schloss, K. B., Poggesi, R. M., Palmer, S. E. (2011). Effects of university affiliation and “school spirit" on color preferences: Berkeley versus Stanford. Psychonomic Bulletin \& Review, 18, 498-504.

Shankar, M. U., Levitan, C., \& Spence, C. (2010). Grape expectations: The role of cognitive influences in color-flavor interactions Consciousness \& Cognition, 19, 380-390.

Sheppard, J. (2017). Revenge is a dish served ICE cold: Bar hits back at a customer's bad Tripadvisor review by naming a frozen cocktail 'the ponce's dungarees' after him. Daily Mail Online, July 24 ${ }^{\text {th }}$. http://www.dailymail.co.uk/news/article-4724266/Bristol-bar-names-newcocktail-scathing-review.html.

Smithers, R. (2008). Smarties manufacturer brings back the blues. The Guardian, February 11 $^{\text {th }}$. https://www.theguardian.com/uk/2008/feb/11/fooddrinks .

Spector, D. (2011). The 11 biggest food flops of all time. Business Insider, February $\mathbf{5}^{\text {th }}$. http://www.businessinsider.com/major-food-flops-2011-1.

Spence, C. (2010a). The color of wine - Part 1. The World of Fine Wine, 28, 122-129.

Spence, C. (2010b). The color of wine - Part 2. The World of Fine Wine, 29, 112-119.

Spence, C. (2015). Visual contributions to taste and flavour perception. In M. Scotter (Ed.), Colour additives for food and beverages (pp. 189-210). Cambridge, UK: Woodhead Publishing.

Spence C. (2016). You taste first with your eyes. Class Magazine, Autumn, 72-75. 
Spence, C. (2017a). Hospital food. Flavour, 6:3. DOI 10.1186/s13411-017-0055-y http://rdcu.be/pRsy

Spence, C. (2017b). People hate silly restaurant gimmicks - but they may make your meal more memorable. The Conversation. http://theconversation.com/people-hate-silly-restaurantgimmicks-but-they-may-make-your-meal-more-memorable-82964.

Spence, C., Okajima, K., Cheok, A. D., Petit, O., \& Michel, C. (2016). Eating with our eyes: From visual hunger to digital satiation. Brain \& Cognition, 110, 53-63.

Spence, C., \& Piqueras-Fiszman, B. (2014). The perfect meal: The multisensory science of food and dining. Oxford, UK: Wiley-Blackwell.

Spence, C., Shankar, M. U., \& Blumenthal, H. (2011). 'Sound bites': Auditory contributions to the perception and consumption of food and drink. In F. Bacci \& D. Melcher (Eds.), Art and the senses (pp. 207-238). Oxford, UK: Oxford University Press.

Spence, C., Wan, X., Woods, A., Velasco, C., Deng, J., Youssef, J., \& Deroy, O. (2015). On tasty colours and colourful tastes? Assessing, explaining, and utilizing crossmodal correspondences between colours and basic tastes. Flavour, 4:23.

Stewart, J. (2011). Cooking up colour. Gastronomica, 11 (Fall), 53-59.

Suk, H. J., Park, G. L., \& Kim, Y. (2012). Bon appetit! An investigation about the best and worst color combinations of lighting and food. Journal of Literature and Art Studies, 2, 559566.

Suzuki, M., Kimura, R., Kido, Y., Inoue, T., Moritani, T., \& Nagai, N. (2017). Color of hot soup modulates postprandial satiety, thermal sensation, and body temperature in young women. Appetite, 114, 209-216.

Tysoe, M. (1985). What’s wrong with blue potatoes? Psychology Today, 19(12), 6-8.

Van Doorn, G., Wuillemin, D., \& Spence, C. (2014). Does the colour of the mug influence the taste of the coffee? Flavour, 3:10.

Velasco, C., Michel, C., Youssef, J., Gamez, X., Cheok, A. D., \& Spence, C. (2016). Colourtaste correspondences: Designing food experiences to meet expectations or to surprise. International Journal of Food Design, 1, 83-102.

Walford, J. (1980). Historical development of food coloration. In J. Walford (Ed.), Developments in food colours (pp. 1-26). London, UK: Applied Science.

Wan, X., Velasco, C., Michel, C., Mu, B., Woods, A. T., \& Spence, C. (2014a). Does the shape of the glass influence the crossmodal association between colour and flavour? A crosscultural comparison. Flavour, 3:3.

Wan, X., Woods, A. T., van den Bosch, J., McKenzie, K. J., Velasco, C., \& Spence, C. (2014b). Cross-cultural differences in crossmodal correspondences between tastes and visual features. Frontiers in Psychology: Cognition, 5:1365.

Wan, X., Woods, A. T., Velasco, C., Salgado-Montejo, A., \& Spence, C. (2015). Assessing the expectations associated with pharmaceutical pill colour and shape. Food Quality \& Preference, 45, 171-182. 
Watson, L. (1971). The omnivorous ape. New York, NY: Coward, McCann, \& Geohhegan.

Wheatley, J. (1973). Putting colour into marketing. Marketing, October, 24-29, 67.

Woods, A. T., Marmolejo-Ramos, F., Velasco, C., \& Spence, C. (2016). Using single colours and colour pairs to communicate basic tastes II; Foreground-background colour combinations. i-Perception, 7:5.

Woods, A. T., \& Spence, C. (2016). Using single colours and colour pairs to communicate basic tastes. i-Perception, 7:4.

Yang, F., Cho, S., \& Seo, H. S. (2016). Effects of light color on consumers' acceptability and willingness to eat apples and bell peppers. Journal of Sensory Studies, 31:3e11.

Youssef, J. (2013). Molecular cooking at home: Taking culinary physics out of the lab and into your kitchen. London, UK: Quintet Publishing. 